\title{
Basic morphometric parameters of the biostatic donkey body model
}

\author{
M. Uroševič ${ }^{*}$ D. Drobnjak, R. Mandić, R. Trailović, G. Stanišić and \\ N. Grittner
}

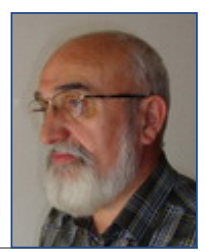

\begin{abstract}
The domestic donkey (Equus asinus) has a very specific body construction. It is built in such a way that the mutual relationship of individual body regions enables great work endurance. The fact that this breed of domestic animal originates from wild ancestors, originated and developed in Africa, clearly shows that the breed developed in harsh climatic and ecological conditions that conditioned the appropriate biological response. The biostatic model causes the biodynamic effect, i.e., the production of biokinetic energy. Movement forwards occurs as a consequence of the creation of biokinetic energy and its transfer from the back part of the body, where it originates, to the front part of the body. The most efficient transfer of biokinetic energy is enabled by the existence
\end{abstract}

of an appropriate biostatic model, i.e., body structure, and this leads to a biodynamic effect that is defined as a movement. For the process of movement, the muscles must be well developed. Two muscle groups are distinguished; a) pelvic muscles, b) external hip and croup joint muscles. The basic lever for the transfer of biokinetic energy is the femur. The generated energy is transferred from the hip joint to the thigh muscles, which shortening leads to the movement of the hind leg forward, its leaning against the ground and pushing the whole body forward. The generated biokinetic energy cause the bio kinematic effect, which is characterized as a movement.

Key words: domestic donkey; body construction; biostatic model

\section{Introduction}

The domestic donkey (Equus asinus) has a very specific body construction. It is built in such a way that the mutual relationship of individual body regions enables great work endurance. The fact that this breed of domestic animal originates from wild ancestors, originated and developed in Africa, clearly shows that the breed developed in harsh climatic and ecological conditions that

Milivoje UROŠEVIĆ*, DVM, MVM, PhD, (Corresponding author: e-mail: milivoje.urosevic@gmail.com), Darko DROBNJAK, DVM, MSc, Center for Preservation of Indigenous Breeds, Belgrade, Serbia; Radomir MANDIĆ, PhD, Assistant Professor, Faculty of Ecology Futura, University Metropolitan, Belgrade, Serbia; Ružica TRAILOVIĆ, DVM, PhD, Associate Professor, Faculty of Veterinary Medicine, University of Belgrade, Serbia; Goran STANIŠIĆ, Professor, PhD, High Agricultural School of Vocational Studies, Šabac, Serbia; Natalija GRITTNER, PhD, Center for Preservation of Indigenous Breeds, Belgrade, Serbia 
conditioned the appropriate biological response. The donkey is a working animal and there is no differentiation of breeds between those for milk production and those for meat production.

The body structure was created, precisely, as a specific biological response to the existing living conditions. Today, there are virtually no geographical areas where the domestic donkey is not used to perform various tasks, most often transport. In countries with high technological development, the role of the domestic donkey is changing significantly. Increasingly, it has found its place in a certain form of tourist offer or sports. Apart from this, it is not uncommon for them to be used as therapeutic animals for special needs children.

Despite the change in role and work tasks, in developed countries around the world, the domestic donkey still performs difficult transport tasks. In order to do that, it is necessary to have an appropriate biostatic model of the body. One of the important, key features is the upgrading of the body. The height of the croup is higher than the height of the ridge (Babić 1938, Essert 1959; Folch and Jordana 1997; Ivanković et al., 2000; Lucia Casini et al., 2007; Yilmaz and Ertugrul 2011, 2012; Yilmaz and Wilson 2013; Urošević et al., 2019).

Every body, including biologically, is built of a massive number of the smallest particles, i.e., cells, to form the biological body. The pull of the Earth - gravity - pulls each individual cell down, acting on each cell with a certain force. The direction of action of these forces is perpendicular to the ground. All these parallels, starting from the individual cell, give the total that represents the mass of the body, and the attack point of the mass is the centre of gravity.

The body mass of a donkey, like any other body, can be represented by the application of a vector (Figure 1, Figure
2). Each mass of a body is defined by: a) intensity - as the measured mass in $\mathrm{kg}$, b) direction of gravity (Earth's gravity), which is vertical, c) direction of force - down, and d) point of attack of force - the centre of gravity. It can be defined as the point of the imagined resultant of all masses of the individual parts of the donkey body, as the sum of all forces (resultant of forces) acting on the body.

There are no information in the available literature on the topographic location of the donkey's body. Based on the basic principles of biokinetics, the centre of gravity is on a horizontal plane, parallel to the ground, which rests atop the sternum (Urošević and Drobnjak, 2018). In order to determine the centre of gravity of the body, i.e., the place of central action of a complex system of forces, it is necessary to know the individual masses of each part of that system and the attack points of those forces.

\section{Biostatic model of the donkey body}

The biostatic model causes the biodynamic effect, i.e., the production of biokinetic energy. Movement forwards occurs as a consequence of the creation of biokinetic energy and its transfer from the back part of the body, where it originates, to the front part of the body. The most efficient transfer of biokinetic energy is enabled by the existence of an appropriate biostatic model, i.e., body structure, and this leads to a biodynamic effect which is defined as movement.

When it comes to the anatomical characteristics of the donkey's body, it should be noted that the number of thoracic vertebrae, and thus the number of ribs, is not constant. Most donkeys have 18 thoracic vertebrae, though there are also individuals with 19 thoracic vertebrae. A donkey has 6 loin vertebrae (Hafner, 2013), unlike a horse that has 7 loin vertebrae (Brem, 1998). 


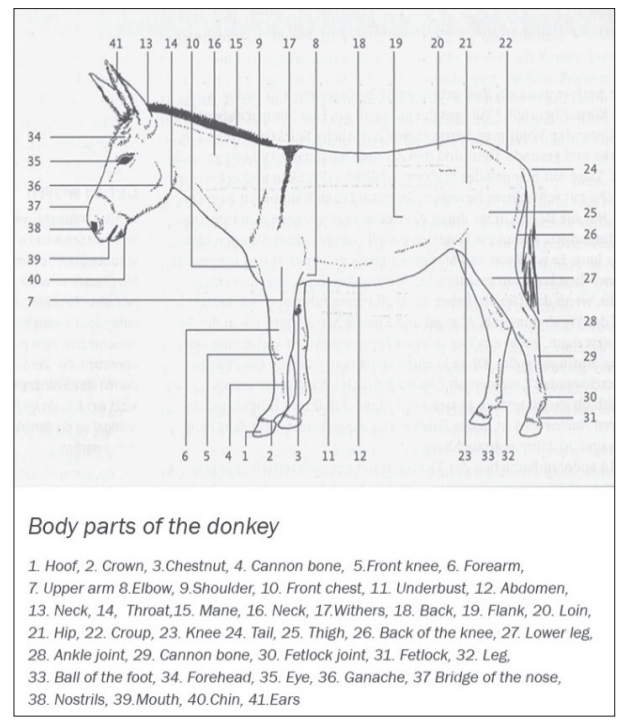

Figure 1. Body parts of the donkey (Hafner, 2013)

The centre of biokinetic energy production is the hip joint (articulatio coxeae). (Figure 3 ). It should be noted that the donkey has a specifically placed pelvis, i.e., the intestinal bone (os illium) is further down than in other animals. This anatomical specificity conditions that the hip joint is lower. The hip joint has a spherical shape and is therefore called Articulatio spheroidae. A healthy, well-built hip joint can move in three planes:

a) Sagittal - it undergoes complex processes of bending (flexiae) and stretching (extensiae)

b) Transverse - in this plane, the hip joint undergoes the processes of approaching (abduktio) and pulling away (adduktio)

c) Vertical-in this plane, it undergoes the processes of "twisting" (pronatio) and "unscrewing" (supunatio).

The hip joint allows bending (flexion), extension (extension), rotation, approaching (abduktio) and pulling away (adduktio).

In addition to the internal movement of the hip joint in these three planes, a

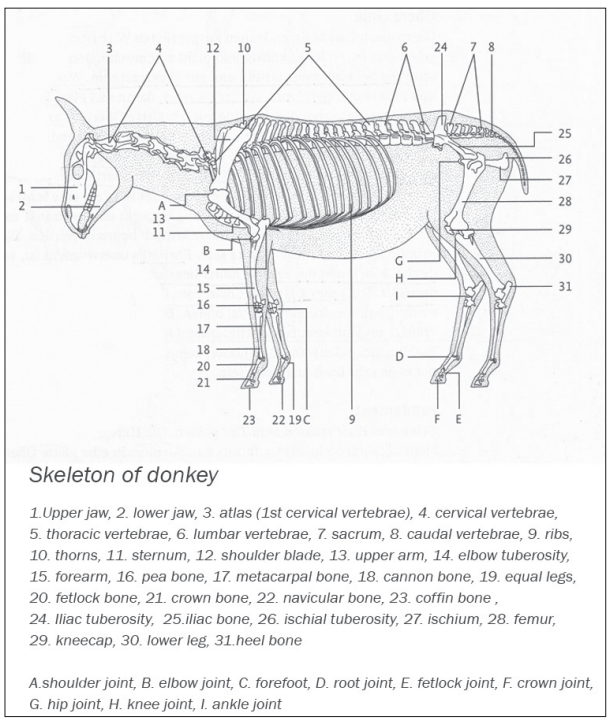

Figure 2. Skeleton of donkey (Hafner, 2013)

certain movement in the form of lateral translation is also possible. This occurs because of the action of the load whose direction of action is directed laterally medially.

The dynamic load of the hip joint during movement, i.e., the transfer of biokinetic energy forward to move the body, is directly related to the magnitude and direction of the force. The total hip load arises as a result of vector addition of forces from the vertical, transverse and horizontal components. The hip joint can withstand a load that is 3-4 times the mass of its own body. The distance between the centre of the femoral head and the medial axis of the body represents the arm of the lever of the existing reversing (spinning). The force acting on the head of the femur, in the acetabulum, is the sum of the forces of the individual levers.

Anatomically, a donkey has the same body parts, even extremities, as a horse, only with certain specifics.

The donkey is characterized by a long and wide pelvis; therefore, the hip joints are set wide (Essert 1959; Ivanković et al., 2000; Urošević et al., 2015, 2019; 


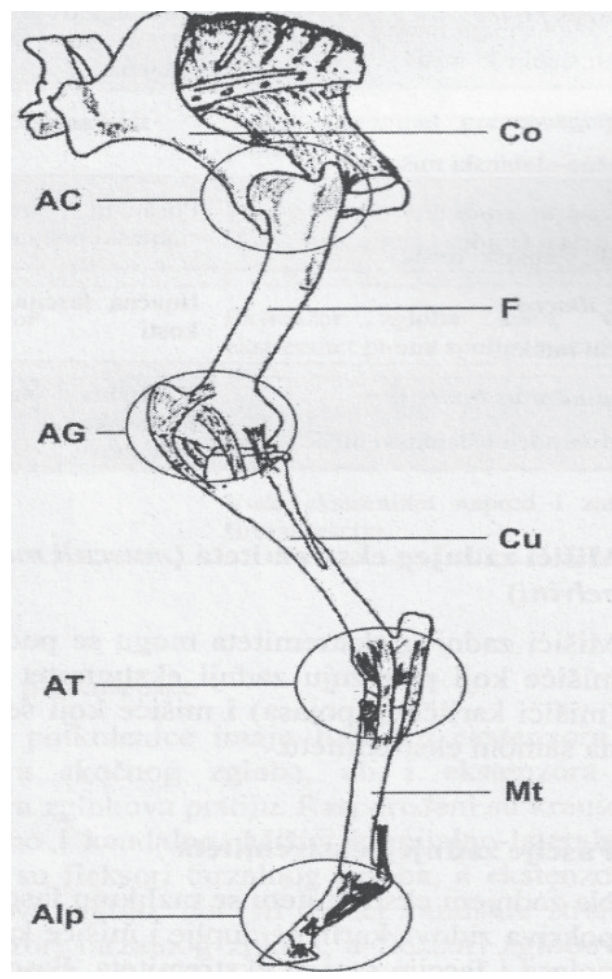

Figure 3. Hind limb of a horse (Žikić et al., 2016)

Legend: Co - ossa coxae, $\mathbf{F}$ - os femoris, $\mathbf{C u}$ - os sacruris, Mt - ossa metatarsi

AC-articulatio coxae, AG - articulatio genus, AT - articulatio tarsi, Alp - articulationnes interphalangespedis

Clara Sargentini et al., 2018). This causes the medial lever to be longer than the lateral, so the muscle strength must be proportionally greater.

The femoral joint (ankle must be very good, the hip joint must be very well closed. The associated musculature, which attaches to the femur and intestinal bone, must be strong, as well as flexors and extensors.

For the process of movement, the muscles must be well developed. Two muscle groups are distinguished; a) pelvic muscles, b) external hip and croup joint muscles (Žikić et al., 2016).

The basic lever for the transfer of biokinetic energy is the femur. The generated energy is transferred from

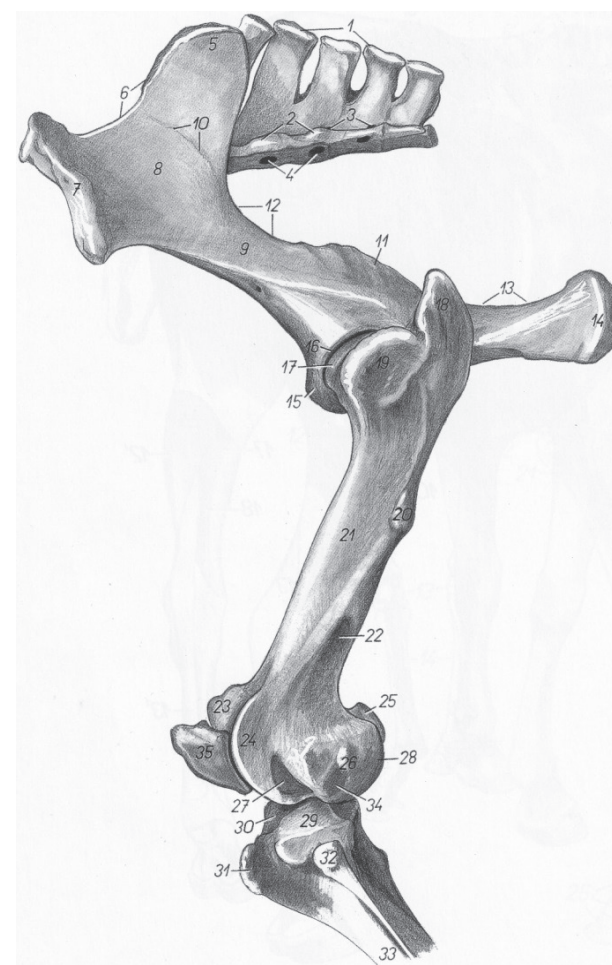

Figure 4. Pelvic skeleton and maxillary hind leg of a donkey lateral side (Popesko, 2004)

Legend: 1. Crista sacralis mediana - middle crest of the croup, 2. Crista sacralislateralis, lateral crest of the croup, 3. Foramina sacralia dorsalia - dorsal openings on the sacral vertebrae, 4. Foramina sacralia pelvina - pelvic sacral openings, 5. Tuber sacrale - sacral hump, 6. Crista iliacalateral ridge, 7. Tuber coxae - lateral hump, 8. Ala ossis illiwing of lateral bone, 10. Linea glutea - tracheal line, 11. Spina ischiadica - sitting ridge, 12. Incisura ischiadica major - large septal concavity, 13. Incisura ischiadica minor - small septal indentation, 14. Tuber ischiadicum - lateral carpal calyx, 15. Eminentia iliopubica - femoral head, 16. Acetabulum - posterior femur, 17. Caput ossis femoris - anterior femur, 18. Pars caudalis traochanter majoris - third femur, 19. Pars cranialis trochanteris majoris - anterior part of a large bump of femur, 20. Trochanter tertius - the third bump of the femur, 21. ossis femoris - femur body 22. Fossa supracondylaris above condylar fossa, 23, 24. Trochlea ossis femoris - femur roller, 25. Condylus medialis ossis femoris - medial femur condyle, 26. Epicondylus lateralis - lateral epicondylus, 27. Fossa extensoria - extensor dent 28. Condylus lateralis ossis femoris - lateral femur bump, 29. Condylus lateralis tibiae - lateral nodule tibia, 30. Eminentia inter condylaris -intercondylar elevation, 31. Tuberositas tibiae - roughness of the lower leg, 32. Caput fibule - head of the lower leg, 33. Corpus tibiae - body of the tibia, 34. Fossa mi. poplitei concave of the lower leg muscle, 35. Patella-calyx 
Table 1. Pelvic girdle muscles (Žikić et al., 2016)

\begin{tabular}{|c|c|c|c|}
\hline The name of the muscle & Begin & The End & Function \\
\hline $\begin{array}{l}\text { M. psoas minor-small } \\
\text { lumbar muscle }\end{array}$ & $\begin{array}{l}\text { The last three thoracic, } \\
\text { vertebrae from the 1st } \\
\text { to the } 4 \text { th lumbar } \\
\text { vertebrae }\end{array}$ & Intestinal bone body & $\begin{array}{l}\text { Strengthens and } \\
\text { moves the lumbar } \\
\text { part of the spin }\end{array}$ \\
\hline \multicolumn{4}{|l|}{$\begin{array}{l}\text { M. illiopsoas-lateral- } \\
\text { lumbar muscle }\end{array}$} \\
\hline $\begin{array}{l}\text { M. psoas major (Large } \\
\text { weak muscle) }\end{array}$ & $\begin{array}{l}\text { The last thoracic and } \\
\text { all lumbar vertebrae }\end{array}$ & Trochanter minor & $\begin{array}{l}\text { Hip joint flexor, pulls } \\
\text { hind limb forward }\end{array}$ \\
\hline M. illacus - lateral muscle & $\begin{array}{l}\text { Iliac fascia, wing of } \\
\text { intestinal bone }\end{array}$ & Trochanter minor & $\begin{array}{l}\text { Hip joint flexor, pulls } \\
\text { hind limb forward }\end{array}$ \\
\hline $\begin{array}{l}\text { M. quadratus lumborum- } \\
\text { four-part loin muscle }\end{array}$ & $\begin{array}{l}\text { Ventral side of the } \\
\text { lateral extensions of } \\
\text { the lumbar vertebrae }\end{array}$ & $\begin{array}{l}\text { Wing of the } \\
\text { intestinal bone and } \\
\text { sacrum }\end{array}$ & $\begin{array}{l}\text { Strengthens the } \\
\text { lumbar spine }\end{array}$ \\
\hline
\end{tabular}

the hip joint to the thigh muscles, which shorten, leading to the movement of the hind leg forward, its leaning against the ground and pushing the whole body forward. The generated biokinetic energy cause the bio-kinematic effect, which is characterized as movement. In relation to the muscles, the basic producers of biokinetic energy are the M. psoas major and pelvic muscles as shown in Table 1.

The large lumbar muscle M. psoas major (large lumbar muscle) whose beginning attaches to the last thoracic and all lumbar vertebrae and ends with attachment to the Trochanter minor, has a fundamental role in hip flexion. The consequence of this mechanical action is the movement of the hind limb in the cranial direction (forward) (Figure 4 and 5). In this very important kinetic phase, in addition to this muscle, the lateral muscle $M$. iliacus also plays an important role in moving the hind limb forward. Its beginning is on the iliac fascia and the wing of the intestinal bone, and it also ends on the Trochanter minor. This muscle is also a flexor of the hip and with its flexion it moves the back limb forward.

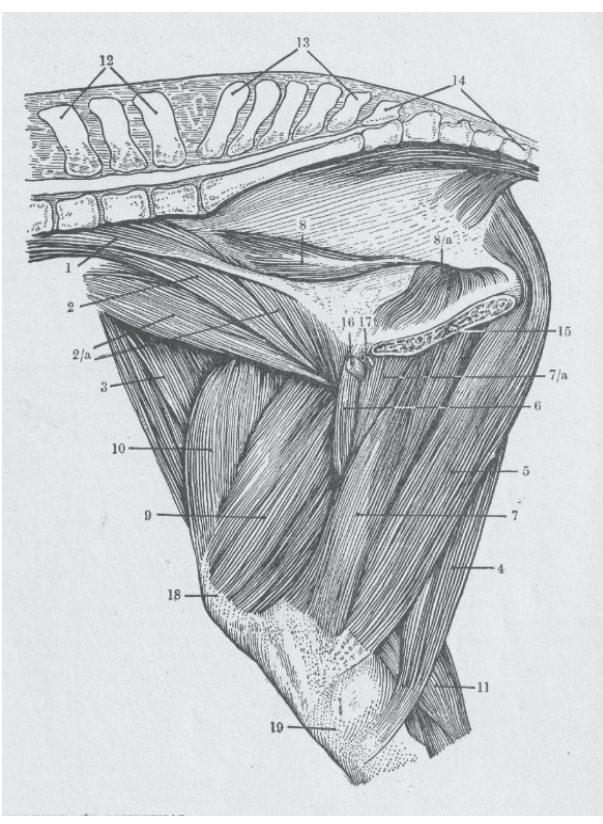

Figure 5. Musculi pelvis et femoris equi (facies medialis) (Ellenberger-Baum, cit. Kovacs 1967) Legend: 1. M. psoas minor, 2. M. psoas major, 2a. M. iliacus, 3. M. tensor fasciae latae, 4. M. semitendinosus, 5 . M. semimembranosus, 6. M. pectineus, 7., 7a. M. adductor, 8.,8/a. M. obturator internus, 9. M. vastus medialis (tibialis), 10. M. rectus femoris, 11. M. gastrocnemius, 12. Vertebrae lumbales. 13. Os sacrum, 14. Vertebrae coccygeae, 15. Symphysis pelvina, 16. Lig. accessorium, 17. Vena pudenda externa, 18. Patella, 19. Tibia 
The donkey is characterized by the possibility of long-term, not fast, movement. The femur is relatively short and therefore the step of the hind leg is short, which causes a short step of the front leg. A short crane can carry a large mass, but it cannot move it over a greater distance. This is how the transfer of biokinetic energy, which is generated in the hip joint, works. In other words, a donkey has short steps, but can move for a very long time. The characteristic possibility of long movement, without significant fatigue, is enabled by the characteristic biostatic model of the body.

There is very little data on the length of the femur and its relationship to the height at the withers and the height of the croup. Urošević et al. (2015) report that the average length of the thigh is $29.86 \pm 3.43 \mathrm{~cm}$ in males, and $30.29 \pm 2.14 \mathrm{~cm}$ in females. Differences in absolute values are not statistically significant. The authors report that the average value of the length of the lower leg is $37.86 \pm 3.15 \mathrm{~cm}$ in males, and $39.00 \pm 3.16 \mathrm{~cm}$ in females. In this case, too, the differences in absolute values were not statistically significant.

When comparing the ratio of the length of the thigh to the total height of croup, this was $28.41 \%$ for males and $28.41 \%$ for females, indicating no differences between the sexes.

The relative ratio of the length of the lower leg to the height of the croup is $36.02 \%$ in males, and $36.58 \%$ in females, as in the case of the length of the thigh and lower leg, it is the same relative ratio of the length of the lower leg to the height of the croup. The study was performed on donkey populations in Romania, North Macedonia and Turkey. In the observed populations, the total average height of the ridge was 101.33 cm (Urošević et al., 2015).

\section{Overview of the literature on donkey morphometry}

By studying the morphometry of the barn donkey, Urošević et al. (2019) determined the average height of male heads of $115.5 \pm 4.5 \mathrm{~cm}$ and the height of the cross of $118.3 \pm 5.7 \mathrm{~cm}$. The height at the withers, on average, in females was $112.2 \pm 5.7 \mathrm{~cm}$ and cross height $117.0 \pm$ $5.4 \mathrm{~cm}$. The length of the thigh was, on average, $31.4 \pm 2.7 \mathrm{~cm}$, and the lower legs $42.4 \pm 3.0 \mathrm{~cm}$. In females, the thigh had an average length of $32.5 \pm 2.1 \mathrm{~cm}$, and the lower leg $41.4 \pm 3.3 \mathrm{~cm}$. When these values are put in relative relation with the height of the croup, a value of $26.54 \%$ is obtained for the length of the thigh for males and $27.78 \%$ for females. The length of the lower leg is $35.84 \%$ of the height of the croup in males, and $35.38 \%$ in females.

The difference in ridge height in these two groups of observed donkeys was 11\% in favour of baroque donkeys, however the relative ratios were the same.

Clara Sargentini et al. (2018) examined the exterior of the Italian breed of Amiata donkeys at four locations and found an average height of the ridge of 126.82 $\mathrm{cm}$. The average value of the length of the thigh was $40.95 \mathrm{~cm}$, and the lower legs $32.12 \mathrm{~cm}$. The average height of the croup was $129.95 \mathrm{~cm}$. This shows that donkeys of this breed have also been upgraded. In terms of the ratios of the length of the thigh and lower leg, in relation to the height of the croup, the result was 31.51\% for the thigh and $24.72 \%$ for the lower legs.

Therefore, different body size does not cause significant changes in the interrelationships of individual morphometric parameters. That is completely justified and logical. Approximately the same biostatic model enables the same principles of biokinetic energy production and bio-kinematic action, i.e., movement. 
Brem (1998) stated that in horses, the optimal value of the angle of the shoulder joint is 90-100 degrees, the elbow joint 130-140 degrees, the knee joint 90-100 degrees, and the ankle joint 130-140 degrees.

Examining the biostatic model of donkeysin Romania, Northern Macedonia and Turkey, Urošević et al. (2017) found that the average value of the angle of the shoulder joint in Romania was $72.8 \pm 3.1$ degrees in males, and $93.8 \pm 9.5$ degrees in females. The interval of variation of the value of the angle of the shoulder joint was from 70.6 to 75.0 degrees in males, and $93.8 \pm 9.5$ degrees in females. The interval of variation of the value of the angle of the shoulder joint was from 70.6 to 75.0 degrees in males, and 70.8 to 104.0 degrees in females. The differences between the sexes were statistically significant $(P<0.05)$.

With regard to the value of the angle of the shoulder joint in donkeys in North Macedonia, the average value was $77.8 \pm$ 2.6 degrees with an interval of variation from 75.0 to 80.0 degrees. In females, the average value of the angle of the shoulder joint was $81.3 \pm 2.5$ degrees, with an interval of variation from 80.0 degrees to 85.0 degrees. As in Romania, there was an observed statistical difference between the sexes in the values of the shoulder joint.

In Turkey, the average value of the angle of the shoulder joint was 80.0 degrees in males with an interval of variation from 75.0 to 85.0 degrees. In females, the average value was $81.7 \pm 5.8$ degrees with a variation interval from 75.0 to 85.0 degrees. In this case, no statistical significance was found between the sexes.

Comparing these results with the statements of Brem (1998) on the optimal value of the shoulder angle by horses, it can be concluded that the examined donkeys in Romania, North Macedonia and Turkey have a more closed angle of the shoulder joint.
Concerning the corners on the hind leg, Urošević et al. (2017) found that the mean value of the knee joint angle was $99.21 \pm 6.80$ degrees in males with a variation interval of 85.0 to 110.0 degrees. In females, the mean value was 108.80 \pm 10.08 degrees, and the interval of variation was from 85.0 to 130.0 degrees. The total observed mean value of the knee joint angle is $104.50 \pm 9.89$ degrees with an interval of variation from 85.0 to 130.0 degrees. Differences in the values of angles between the sexes were statistically very significant $(P<0.01)$.

The mean value of the ankle angle in males was $128.90 \pm 12.58$ degrees with an interval of 104.0 to 145.0 degrees. In females, the mean value was 129.90 \pm 11.95 degrees, with an interval of variation from 95.0 to 145.0 degrees. The total observed mean value of the ankle angle was $129.40 \pm 12.04$ degrees with a range of variation from 95.0 to 145.0 degrees. The differences in the values of the ankle angles between the sexes are not statistically significant.

When these values are compared with the optimal values for horses (Brem, 1998), it can be observed that the minimum value of the ankle angle in donkeys is lower than in horses, indicating a more closed ankle, while the maximum values are the same for donkeys and horses.

Unlike the hind legs, which generate biokinetic energy, the front legs do not have such a role. During the movement that moves, or "pushes", the body forward, the front legs accept the mass of the body by their movement and enable the cyclic genesis of biokinetic energy with the back legs.

In the whole process of movement, as well as standing, the centre of gravity has a very important role. The further the centre of gravity is shifted backwards (caudally), the more the rear part of the body is loaded, i.e., it carries about $60 \%$ of the body weight, and the front part $40 \%$. In this case, the rear part of the 
body must first use the biokinetic energy produced to carry that part of the body mass, and the remaining part serves to push the body forward, i.e., move. If the centre of gravity is shifted more forward (cranially), then the share in carrying body weight changes significantly. Then the load is $60 \%$ on the front part of the body, and $40 \%$ on the back part. This lightened back of the body consumes significantly less biokinetic energy to carry the body (Figure 6).

The position of the centre of gravity is defined by the intersection of the horizontal and vertical planes. When it comes to the horizontal position of the centre of gravity, it is defined and is located at the level of the top of the sternum, and its position is defined by intrauterine development. Moving the centre of gravity is possible only in the horizontal plane "forward-back". There is no information in the available literature as to which morphological segment occurs the intersection of the horizontal and vertical planes.

There are two basic morphometric factors that define the position of the centre of gravity. This is the position (and height) of the croup, and the position of the neck and the angle at which it is implanted in the body.

Two postulates can be defined here:

1. Neck set relatively low, implanted in the body at an angle of up to 30 degrees and croup set high, higher than the height at the withers

2. Neck set high, planted at an angle greater than 30 degrees and the croup placed at the height of the ridge or lower than the ridge.

In the available literature, there is scarce data on the angles of the croup and neck. Urošević et al. (2015) stated that the average value of the croup angle in males is $1.0 \pm 3.92$ degrees, with an interval of variation from 10.0 to 20.0 degrees. In females, the average value of the angle at which the croup is placed is $18.35 \pm 4.59$ degrees and variation from 10.0 to 25.0 degrees. These differences are statistically significant $(P<0.05)$.

Urošević et al. (2019) reported on the angle at which the neck of a baroque donkey is implanted, giving an average value of $24.0 \pm 5.4$ degrees for males, with a rather large interval of variation, from 15.0 to 30.0 degrees. In females, the average value of the angle at which the neck is implanted in the body is $22.1 \pm$ 5.2 degrees with a variation interval from 15.0 to 30.0 degrees.

These two basic biostatic postulates define the position of the centre of gravity. In the first case, which is a desirable biostatic model of the donkey's body, the centre of gravity is shifted forward. This increases the biodynamic possibility, i.e., the back part of the body is more relieved than the front one. The production of biokinetic energy is at the appropriate level and the typical biokinematic action, i.e., the movement of the donkey, is realized.

In the second case, which is undesirable and is not found in normally developed donkeys, the centre of gravity is shifted backwards. This causes a greater load on the back of the body, making it difficult to produce biokinetic energy. Insufficient energy level does not allow easy movement. So, this explains why donkeys are upgraded, and the rear of the body is higher than the front.

Studying the morphometric parameters of donkeys, Urošević et al. (2019) found an average croup height of $106.6 \pm 3.2 \mathrm{~cm}$ in males, and $105.7 \pm 3.5$ $\mathrm{cm}$ in females. (Table 2). These differences were not statistically significant. At the same time, the average height of the sternum tip was $70.9 \pm 2.4 \mathrm{~cm}$ in males and $66.3 \pm 3.3 \mathrm{~cm}$ in females. These differences were statistically highly significant $(P<0.001)$. (Table 3$)$.

These morphological characteristics of the biostatic model and their strong significant statistical differences confirm the the- 
Table 2. Mean values of heights of certain morphometric parameters of baroque donkey females (Urošević et al., 2019)

\begin{tabular}{|c|c|c|c|c|c|c|}
$\begin{array}{c}\text { Ridge } \\
\text { height } \\
\text { (cm) }\end{array}$ & $\begin{array}{c}\text { Back } \\
\text { height } \\
\text { (cm) }\end{array}$ & $\begin{array}{c}\text { Back } \\
\text { cross } \\
\text { height } \\
\text { (cm) }\end{array}$ & $\begin{array}{c}\text { Height } \\
\text { of top of } \\
\text { sternum } \\
\text { (cm) }\end{array}$ & $\begin{array}{c}\text { Shoulder } \\
\text { height } \\
\text { (cm) }\end{array}$ & $\begin{array}{c}\text { Elbow } \\
\text { height } \\
\text { (cm) }\end{array}$ & $\begin{array}{c}\text { Height of } \\
\text { knee joint } \\
\text { (cm) }\end{array}$ \\
\hline $112.2 \pm 5.7$ & $109.3 \pm 5.2$ & $117.0 \pm 5.4$ & $75.6 \pm 2.5$ & $80.3 \pm 2.9$ & $68.5 \pm 3.1$ & $71.2 \pm 4.6$ \\
\hline
\end{tabular}

Table 3. Mean values of heights of certain morphometric parameters of baroque donkey males (Urošević et al., 2019)

\begin{tabular}{|c|c|c|c|c|c|c|}
$\begin{array}{c}\text { Ridge } \\
\text { height } \\
(\mathrm{cm})\end{array}$ & $\begin{array}{c}\text { Back } \\
\text { height } \\
(\mathrm{cm})\end{array}$ & $\begin{array}{c}\text { Back } \\
\text { cross } \\
\text { height } \\
(\mathrm{cm})\end{array}$ & $\begin{array}{c}\text { Height } \\
\text { of top of } \\
\text { sternum } \\
\text { (cm) }\end{array}$ & $\begin{array}{c}\text { Shoulder } \\
\text { height } \\
\text { (cm) }\end{array}$ & $\begin{array}{c}\text { Elbow } \\
\text { height } \\
(\mathrm{cm})\end{array}$ & $\begin{array}{c}\text { Height of } \\
\text { knee joint } \\
\text { (cm) }\end{array}$ \\
\hline $115.2 \pm 4.5$ & $112.8 \pm 6.5$ & $118.3 \pm 5.2$ & $77.0 \pm 5.7$ & $81.2 \pm 2.4$ & $71.0 \pm 2.5$ & $73.6 \pm 3.7$ \\
\hline
\end{tabular}

oretical axion which says: "The higher the centre of gravity, the animal is faster, but more unstable. The lower centre of gravity causes slower movement, but greater stability". From a biological point of view, it is completely justified that females have a lower centre of gravity. Pregnant females must be stable when moving, and it is not desirable for them to move fast.

When these values are set in proportional relations, it is found that males of the observed population had the top of the sternum at $66.51 \%$ of the height of the croup or $67.59 \%$ of the height of the ridge. In females, this was $62.72 \%$ of the height of the croup and $65.32 \%$ of the height of the ridge.

In both sexes, the knee joint is placed at a higher height than the elbow joint, and at a lower height than the shoulder joint. Thus, the knee joint is in a horizontal plane that passes between the shoulder and elbow joint in both sexes, and the knee joint is placed lower than the top of the sternum, i.e., the centre of gravity.

It is interesting to look at the ratio of the height of the ankle joint (tarsal joint - articulatio tarsi). This anatomical part is a complex joint which, practically, consists of four joints, formed due to the articulation of the lower bones - tibia and fibula, tarsal and metatarsal bones. Brem (1998) states that the optimal value of the ankle in horses is 135-140 degrees. There is scarce data in the available literature on the value of the ankle angle by donkeys. Urošević et al. (2019) studied the structure of the baroque donkey in Austria and reported an average value of the ankle angle of $128.0 \pm 9.1$ degrees in males and $130.7 \pm 6.2$ degrees in females. In analysing morphometric parameters by donkeys in Turkey, Romania and North Macedonia, Urošević et al. (2015) found that in the total population, the mean value of the ankle angle was 104.00 degrees in males and 95.00 degrees in females. These differences in absolute values were not statistically significant.

Ankle height in males of baroque donkey was on average $45.6 \pm 1.6 \mathrm{~cm}$, and $43.7 \pm 3.0 \mathrm{~cm}$ in females. If these values are set in relation to the height at the withers, then the height of the ankle is $39.48 \%$ for males and $38.95 \%$ for females. In the total population from Turkey, Romania and North Macedonia, the relative ratio of the height of the ankle joint and ridge height was $32.57 \%$ for males, and also $32.57 \%$ for females. 
Regardless of its basic slow movement, the donkey can move at a trot and gallop. It is not uncommon that they can move like a camel, when the legs on one side of the body move at the same time. When galloping, they can reach speeds of up to $70 \mathrm{~km} / \mathrm{h}$, but this is not characteristic. Step-by-step movement is a typical movement and then the donkey can cross $3.2 \mathrm{~km}$ per hour (Hafner, 2013). Generally, the donkey can achieve a speed of $4-5 \mathrm{~km} / \mathrm{h}$ for walking, $7-12 \mathrm{~km} / \mathrm{h}$ for a trot, and $13-20 \mathrm{~km} / \mathrm{h}$ for a gallop.

Step length depends on the height of the ridge or the size of the donkey. Babic (1939) discussed the size of the steps and the speed of movement. Studying the Apulian donkeys, which were imported

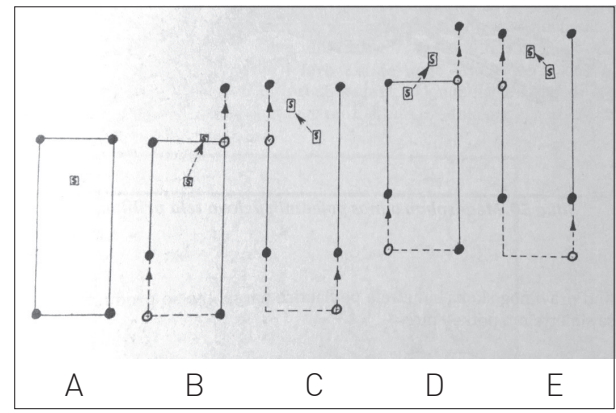

Figure 6. Shifting the centre of gravity

Legend:

A. While standing still, with all four legs on the ground, it is possible to draw a rectangle in which is the centre of gravity

B. Movement begins, the front right and back left legs move. The centre of gravity moves towards the front right leg as its movement shifts the total load. The centre of gravity does not go beyond the frame when the front left and right hooves are outlined. The front right and rear (back) left leg leaned on the mainland

C. After the support of the front right and rear left, the action of the front left and rear right legs begins. Now the centre of gravity moves towards the direction of movement of the front left leg.

D. When the front left and rear right leg lean the cycle starts again with moving the front right and back left, the centre of gravity moves to the right, in the direction of moving the right leg

E. Cycle continues by moving the front left and back right and so alternately donkey is moving (Stockmann, 1985, cit. Urošević and Drobnjak 2018). to Dalmatia, he found an average step length of $1.44 \mathrm{~m}$ for males, and $1.41 \mathrm{~m}$ for females. It is interesting that both sexes realized a step in $0.98 \mathrm{sec}$. The author determined that the average height of the ridge of the examined donkeys was 128.8 $\mathrm{cm}$.

When moving, the crossed legs always move - front left, back right; front right, back left. By moving the legs, the load on the mass also shifts, and that cause the movement of the centre of gravity in the direction of moving the front leg.

\section{References}

1. BABIĆ, E. (1938): Prilog poznavanju apuljskih magaraca u Dalmaciji. Vet. arhiv 9, 228-252.

2. BREM, G. (1998): Exterieu beurteilung landwirtschaftlicher Nutztiere, Ulmer Verlag. Stuttgart.

3. CASINI, L., M. SGORBINI, L. MAGNI and M. COREZZA (2007): Valutazioni Morfologische nell Asino Sorcino Croaciato dellAmiata. Ippologia 18, 33-35. (In Italian).

4. ESSERT, Z. (1959): Domaći magarac otoka Mljeta. Veterinaria 1, 41-54.

5. FOLCH, P. and J. JORDANA (1997): Characterization, Reference, Ranges and the Influence of Gender on Morphological Parameters of the endangered Catalonian Donkey Breed. J. Equine Vet. Sci. 17, 102-111. 10.1016/S07370806(97)80347-4

6. HAFNER, M. (2013): Eselhalten. Ulmer Verlag. Stuttgart.

7. IVANKOVIĆ, A., P. CAPUT, B. MIOČ and V. PAVIĆ (2000): The Phenotype Features of Donkeys in Croatia. Agric. Conspec. Sci. 65, 99-105.

8. KOVACS, G. (1967): Haziallatok Anatomiajanak Atlasza. Mezogazdasagikiado, Budapest.

9. POPESKO, P. (2004): Atlas topografske anatomije domaćih životinja, Medicinska naklada Zagreb.

10. SARGENTINI, C., R. TOCCI, A. MARTINI and R. BOZZI (2018): Morphological characterization of Amiata donkey through Multivariate analyses. Braz. J. Vet. Res. Anim. Sci. 47:e20170310, 1-10. 10.1590/rbz4720170310

11. UROŠEVIĆ, M. i D. DROBNJAK (2018): Biomehanika i kretanje pasa. Kinološka akademija, Beograd.

12. UROŠEVIĆ, M. M., M. NEMECEK, D. DROBNJAK, M. B. UROŠEVIĆ, P. STOJIĆ, D. MATARUGIĆ i N. PRAČIĆ (2015): Uglovanost i odnos morfometrijskih parametara na zadnjoj nozi magarca. Radovi sa XXIX savetovanja agronoma, veterinara, tehnologa i agroekonomista. 21, 133-137.

13. UROŠEVIĆ, M. M., M. NEMECEK, D. DROBNJAK, M. B. UROŠEVIĆ, P. STOJIĆ, G. STANIŠIĆ, N. 
PRAČIĆ i D. MATARUGIĆ (2017): Uglovanost prednje noge magarca (Equus asinus). Radovi sa XXXI savetovanja agronoma, veterinara, tehnologa i agroekonomista. 23, 75-79.

14. UROŠEVIĆ, M., M. NEMECEK, D. DROBNJAK and P. STOJIĆ (2019): Morphometric parameters body in donkey. Vet. stn. 50, 133-136. (In Croatian).

15. UROŠEVIĆ, M., M. NEMECEK, D. DROBNJAK, A GANGL, P. DAMESKI, P. STOJIĆ and G. STANIŠIĆ (2019): Morphological Characterization of the White Baroque Donkey. Animal Health, Prod. Hyg. $8,627-633$.
16. YILMAZ, O. and M. ERTUGRUL (2011): Some Morphological Traits of Donkeys Raised in Igdir, Turkey. Univ. J. Inst. Sci. Tech. 1, 113-116.

17. YILMAZ, O. and M. ERTUGRUL (2012): The Morphologic Traits of Donkeys Raised in East and Southeast of Turkey. Hayvansal Üretim 53, 10-13.

18. YILMAZ, O. and T. WILSON (2013): The Domestic Livestock Resources of Turkey: Notes on Donkeys. J. Anim. Plant Sci. 23, 651-656.

19. ŽIKIĆ, D., G. UŠĆEBRKA i S. STOJANOVIĆ (2016): Morfologija životinja. Poljoprivredni fakultet, Novi Sad.

\section{Osnovni morfometrijski parametri biostatičkog modela tijela magarca}

Dr. agr. sc. Milivoje UROŠEVIĆ, dr. med. vet. spec., mr. sc. Darko DROBNJAK, dr. med. vet., COAR - Centar za očuvanje autohtonih rasa Beograd, Srbija; dr. sc. Radomir MANDIĆ, docent, Fakultet za primenjenu ekologiju, Univerzitet Metropolitan, Beograd, Srbija; dr. sc. Ružica TRAILOVIĆ, dr. vet. med., izvanredna profesorica, Fakultet veterinarske medicine, Univerzitet u Beogradu, Srbija; dr. agr. sc. Goran STANIŠIĆ, profesor, dipl. inž. polj., Viša poljoprivredna škola, Šabac, Srbija; dr. sc. Natalija GRITTNER, COAR - Centar za očuvanje autohtonih rasa Beograd, Srbija

Domaći magarac (Equus asinus) ima specifičnu konstrukciju tijela. Građen je tako da međusobni odnos pojedinih dijelova tijela omogućava veliku radnu izdržljivost. Činjenica je da ova vrsta domaćih životinja potječe od divljih predaka nastalih i razvijenih u Africi, jasno ukazuje da se vrsta razvila u surovim klimatskim i ekološkim uvjetima koji su uvjetovali odgovarajući biološki odgovor. Biostatički model uvjetuje biodinamički efekt, odnosno produkciju biokinetičke energije. Kretanje, odnosno pomicanje tijela prema naprijed nastaje kao posljedica stvaranja biokinetičke energije i njezinog prenošenja od zadnjeg dijela tijela gdje i nastaje, prema prednjem dijelu tijela. Najefikasnije prenošenje biokinetičke energije omogućeno je postojanjem odgovarajućeg biostatičkog modela, odnosno građe tijela, što dovodi do biodinamičkog efekta, koji definiramo kao kretanje. Da bi se odvijao proces kretanja nužni su dobro razvijeni mišići. Razlikuju se dvije skupine mišića; a) mišići zdjeličnog područja, b) vanjski mišići zgloba kuka i sapi. Osnovna poluga za prijenos biokinetičke energije je bedrena kost. Generirana energija se iz zgloba kuka prenosi na bedrene mišiće čijim skraćivanjem dolazi do kretanja zadnje noge prema naprijed, njezino oslanjanje o tlo i guranje cijelog tijela prema naprijed. Generirana biokinetička energija uvjetuje biokinematički efekt koji nazivamo kretanjem.

Ključne riječi: domaći magarac, konstrukcija tijela, biostatički model 